\title{
READINESS OF ELEMENTARY SCHOOL TEACHERS TO CURRICULUM CHANGES IN THE DEVELOPMENT OF TEACHING INFORMATICS IN CZECH REPUBLIC
}

\author{
Hana BUČKOV $A^{*}$, Univerzita Palackého v Olomouci, Česká republika
}

Přijato: 27. 6. 2018 / Akceptováno: 19. 8. 2018

Typ článku: Teoretická a výzkumná studie

DOI: $10.5507 /$ jtie.2018.006

Abstract: In this paper we discuss the history and current state of teaching informatics at basic schools in the Czech Republic; also we deal with the initial phase of the evaluation of the research which is focused on the content of educational subject informatics of the lower secondary education of basic schools. We are investigating the opinions of teachers concerning the readiness to curriculum changes in the educational area of informatics and communication technology of the lower secondary education of basic schools. In the context of topically planned curriculum change, our aim is to find out which of the topics that teachers go over or topics which are newly considered, experienced teachers regard as significant and should be inseparable part of teaching. The research is taking place in the connection with the existence of working (unauthorized) version of - Framework Education Programme - the part relevant to informatics and digital technologies.

From the methodological point of view it was chosen a method that enable deeply pervade under the surface of solved problem and instead of usually used questionnaire research it was chosen $Q$ - methodology. The respondents were presented cards with the themes reflecting the informatics and information and communication technologies schoolwork which in accordance with the rules of $Q$ - methodology they sorted them from the most important to the least ones according to assigned criteria. Afterwards their answers were evaluated.

This pre-research shows that informatics teachers focus the teaching mainly on learning user skills. The most favoured themes were focused on the safety in connection with the Internet, the content of office programmes (text editor and spreadsheet, programmes for giving presentations and the like) and basic computer operation. It is noteworthy that teachers do not view the teaching algorithm development and programming as the most significant part of current teaching informatics. These facts lead us to the conviction of necessity to continue the initiated research work. In accordance with the ascertained knowledge the optimization of the number q-types (cards) - the reduction from 90 to 60, went off for the need of the next exploration.

Key words: Informatics, digital literacy, informatics thinking, Framework Education Programme, curriculum, Q-methodology. 


\section{PŘIPRAVENOST UČITELŮ ZÁKLADNÍCH ŠKOL NA KURIKULÁRNÍ ZMĚNY VE VÝUCE INFORMATIKY V ČESKÉ REPUBLICE}

Abstrakt: Př́spěvek pojednává o historii a současné podobě výuky informatiky na základnich školách $v$ České republice a dále se v návaznosti na uvedené skutečnosti zabývá vyhodnocením počátečni fáze výzkumného šetření, které je zaměreno na obsah vzdělávání predmětu informatika na 2. stupni základních škol. Názory učitelì jsou zjištovány ve vazbě na připravované kurikulární změny ve vzdělávaci oblasti Informační a komunikačni technologie na 2. stupni základnich škol. V kontextu aktuálně plánované změny kurikula je cílem zjistit, která z probiraných anebo nově uvažovaných témat považuji učitelé z praxe za významná a měla by být součstí výuky. Výzkum probíhá ve vazbě na existenci pracovni (neschválené) verze rámcového vzdělávacího programu - části týkající se informatiky a digitálnich technologií.

Z metodologického hlediska byla zvolena výzkumná metoda umožňujicí proniknout hlouběji pod povrch řešeného problému a místo obvykle uživaného dotazníkového šetreni byla zvolena Q-metodologie. Respondentüm byly predloženy karty $s$ tématy odrážejíci učivo informatiky a informačních a komunikačnich technologií, které v souladu s pravidly Q-metodologie tř́dili podle zadaných kritérii od nejdi̊ležitějšich po nejméně důležité. Následně byly jejich odpovédi vyhodnoceny.

$Z$ provedeného předvýzkumu se jeví, že učitelé informatiky zaměřjí výuku převáżně na osvojování uživatelských dovedností. Nejvice preferovaná témata byla zaměrena na bezpečnost ve spojeni s Internetem, obsahem kancelářských programu (textový a tabulkový editor, programy pro tvorbu prezentaci atp.) a základní obsluhu počitače. Pozoruhodné je, že učitelé výuku algoritmizace a programování nevnímaji jako nejvýznamnějši součást současné výuky informatiky. Tyto skutečnosti nás vedou $k$ presvědčení o nutnosti pokračovat $v$ započatých výzkumných pracích. V souladu se zjištěnými poznatky proběhla pro potřeby dalšiho zkoumáni optimalizace počtu q-typú (karet) - redukce z 90 na 60.

Klíčová slova: informatika, digitální gramotnost, informatické myšlení, rámcový vzdělávací program, kurikulum, q-metodologie.

5. This journal was approved on 2015-04-23 according to ERIH PLUS criteria for inclusion.

*Autor pro korespondenci: hana.buckova02@upol.cz 


\section{1 Úvod}

Současná podoba výuky informatiky je nejen na základních školách podrobována změnám. Aktuálně probíhají s tím spojené procesy relativně skrytě, učitelé ve školách $\mathrm{v}$ podstatě nejsou o změnách informování, pouze se lze setkat $\mathrm{s}$ informacemi v médiích, které bud' upozorňují na potřebu realizace změn nebo přinášejí informace o již nastartovaných inovačních aktivitách, srov. J. Vaníček (2017), J. Fidrmuc (2017), Informatické myšlení (2017) a další.

Navržení inovovaného obsahu (učiva) a jeho veřejná diskuse je významným krokem pro nastartování procesu změn, nicméně následné anebo se i překrývající fáze nejsou o nic méně významné. Zejména je nezbytné vytvořit kvalitní učební pomůcky (ideálně v praxi ověřené učebnice) a zajistit prŕslušné materiální technické vybavení. Za mimořádně podstatný však pokládáme prvek výuky, kterým je učitel samotný, jeho smýšlení o podobě výuky o tom co, proč, koho, jakým obsahem a za jakých dalších podmínek bude informatiku vyučovat. I dobře navržené osnovy jsou pro zajištění kvalitní výuky málo. Učitel je klíčovým prvkem, to on ve velké míre ovlivňuje, co a jak se na konkrétních školách učí. Díky tomu i výuka, která je obsahově zaměřena na stejné téma, může doznávat odlišných podob a dosahovat různých výstupů $\mathrm{v}$ rovině vědomostí, dovedností a postojů žáků. Didaktickou hodnotu vtiskuje učivu v převážné míře až učitel.

Aktuálně však narážíme na problém. Inovovaný obsah vzdělávání je stanoven a diskutován, méně však známe postoje a názory učitelů na realizaci kurikulárních změn a k inovovanému pojetí výuky informatiky. Jsou inovacemi nadšeni nebo by raději zachovali stávající podobu? A pokud by oni měli ovlivnit obsahovou podobu výuky informatiky, tedy to, čemu se konkrétně učí, jaká témata by preferovali? Uvedené otázky pokládáme za velmi závažné, a i okolnosti nasvědčují tomu, že mohou významně ovlivnit úspěch jakékoliv kurikulární reformy. To je důvodem, proč podrobujeme danou problematiku systematickému zkoumání. Cílem výzkumného šetření je zjištění názorů učitelů na připravované změny kurikula a plánovanou výuku algoritmizace a programování, která u žáků mj. podporuje rozvoj logického myšlení.

\section{Stav výuky informatiky na 2. stupni základních škol v letech 1991-2005}

Do roku 1991 nebyly v České republice informační a komunikační technologie zařazeny do vzdělávacích programů. Jak uvádí J. Dostál a X. Wang (2017) až od roku 1991 existoval volitelný předmět Informatika, který byl určen pro 7. a 8. ročník základních škol a byl po obsahové stránce velmi dobře propracován. Po prodloužení studia o 9. ročník bylo učivo Informatiky a ICT začleňováno do výuky ve větší míře. Předměty měly různé názvy podle toho, co určitá škola měla k dispozici, co považovala za důležité ve výuce a co předmět obsahoval za učivo, napřr. Práce s počítačem, Informační výchova, Výpočetní technika, Informatika nebo Praktikum práce s počítačem.

V září roku 1996 vešel v platnost pod č.j. 16 847/96 nový vzdělávací program Základní škola, ve kterém nebyl předmět Informatika obsažen jako samostatný. V předmětu Praktické činnosti bylo vymezeno několik hodin pro vzdělávání na počítači na základní uživatelské úrovni. Obsah byl následující:

- základní informace o počítači, jeho činnosti a o možnostech jeho využití; programové vybavení počítače;

- $\quad$ ovládání klávesnice, zahájení a ukončení práce na počítači;

- uchování informací, pevný disk, disketa, kopírování;

- $\quad$ obsluha př́idavných zařízení (tiskárna...); 
- obsluha počítače pro hry;

- $\quad$ práce s hotovými didaktickými programy;

- osvojování si základních uživatelských dovedností.

V září 1997 vstoupil v platnost vzdělávací program Národní škola, který byl rozdělen na dvě části. Povinný blok obsahoval přesný počet vyučovacích hodin s vymezeným obsahem učiva a nadstavbový blok mohli ředitelé základních škol a pedagogická rada volitelně měnit. Díky tomu se ve školách objevily předměty Výpočetní technika a Pravděpodobnost, statistika a informatika, jež byly zaměřeny na rozvoj nadaných žáků. Tento program však neměl př́liš velký dopad, jelikož zahrnoval jen malé procento základních škol.

Ani ve třetím vzdělávacím programu Obecná škola, platným taktéž od záríi 1997, nebyla Informatika zařazena do povinné výuky. Práce s počítačem byla však zahrnuta do předmětu Informační výchova, Technická výchova, Technická praktika a Základy práce s počítačem.

Vybavenost základních škol byla různá. Některé školy byly vybaveny dostatečným množstvím nových počítačů, jiné měly pro žáky pouze několik zastaralých počítačů. Výuka se na základních školách lišila $\mathrm{v}$ náplních předmětu i ve výstupním standardu žáka.

\section{Současný stav výuky informatiky na 2. stupni základních škol}

Výuka informačních a komunikačních technologií byla jako povinná součást vzdělávání na základních školách zařazena do Rámcového vzdělávacího programu (dále jen RVP) 1. 9. 2005 (Národní ústav pro vzdělávání, 2005). Výuka od té doby probíhá $\mathrm{v}$ časové dotaci jedna hodina týdně $\mathrm{v}$ jednom ročníku na 1 . stupni a $\mathrm{v}$ jednom ročníku na 2. stupni. Od 1. 9. 2007 školy tvoří školní vzdělávací programy (dále jen ŠVP). Národní ústav pro vzdělávání uvádí přehled úprav RVP ZV od doby jeho schválení do současnosti a dále také opatření př́slušných ministrů školství, mládeže a tělovýchovy (viz. Národní ústav pro vzdělávání, 2018). Vzdělávací oblast informační a komunikační technologie do úprav od roku 2007 zahrnuta nebyla a je po obsahové stránce stále shodná. Dle aktuálního RVP (Ministerstvo školství, mládeže a tělovýchovy, 2017) je výstupní standard pro žáky 2 . stupně základních škol:

- ověřuje věrohodnost informací a informačních zdrojů, posuzuje jejich závažnost a vzájemnou návaznost;

- ovládá práci s textovými a grafickými editory i tabulkovými editory a využívá vhodných aplikací;

- uplatňuje základní estetická a typografická pravidla pro práci $\mathrm{s}$ textem a obrazem;

- $\quad$ pracuje s informacemi v souladu se zákony o duševním vlastnictví;

- $\quad$ používá informace z různých informačních zdrojů a vyhodnocuje jednoduché vztahy mezi údaji;

- $\quad$ zpracuje a prezentuje na uživatelské úrovni informace $\mathrm{v}$ textové, grafické a multimediální formě.

$\mathrm{S}$ rozvojem digitálních technologí je nutné tuto oblast inovovat $\mathrm{v}$ souladu s vyvíjejícím se digitálním světem. J. Vaníček (2017) uvádí, že se děti v hodinách informatiky učí psát ve Wordu, dělat tabulky v Excelu nebo se dozvídají o součástech 
počítače. Taková výuka je $\mathrm{v}$ porovnání s progresivnějšími zeměmi zastaralá. Děti ve Finsku nebo Estonsku mají základy programování od nejnižších ročníkủ základní školy již několik let.

Česká republika se dlouhodobě účastní mezinárodních šetření v oblasti vzdělávání. Mezi ta nejdůležitější patř̌́ šetření organizovaná Organizací pro hospodářskou spolupráci a rozvoj (OECD) a Mezinárodní asociací pro hodnocení výsledků vzdělávání (IEA). Vzhledem ke stále se zvyšující roli počítačových technologií ve společnosti a v životech jedinců se lze bez pochyby domnívat, že ti, kteří neovládnou alespoň základní dovednosti práce s počítačem a technologiemi obecně, budou mít obtíže se v některých aspektech života zapojit do společnosti. Z výsledků mezinárodního šetření PISA vyplývá, že $96 \%$ českých žáků ve škole má prístup ke stolnímu počítači, přenosnému počítači či tabletu. Podíl žáků, kteří tyto technologie ve škole využívají, je v mezinárodním srovnání nadprůměrný. $\mathrm{V}$ tomto srovnání čeští žáci využívají $\mathrm{v}$ nadprůměrné miře počítač $\mathrm{k}$ volnočasovým účelům (Česká školní inspekce, 2016).

V České republice jsou připravovány změny, po nichž by mělo být vzdělávání více provázáno s digitálním světem a reagovat na technologický vývoj. Odborníci jako napřr. J. Vaníček (2017), J. Wagner (2008) a O. Neumajer (2017) v poslední době kritizují koncepci výuky informatiky na českých školách. Národní ústav pro vzdělávání již chystá nové vzdělávací programy (viz NúV, 2017), kde jedním z cílů bude rozvoj informatického myšlení. Podle nového vzdělávacího programu bude výuka informatiky mimo jiné zaměřena na výuku programování. $V$ současném pojetí převládá názor, viz J. Vaníček (2017), že základní znalosti v oblasti práce s počítačem si žáci osvojí v jiných předmětech, kde je prakticky využijí. Textový editor se žáci naučí používat v hodinách češtiny nebo cizího jazyka, tabulkový procesor využijí v matematice nebo jiných prírodních vědách. Prezentační nástroje by pak měli žáci používat ve všech předmětech. Informatika jako předmět bude znamenat nejen výuku programování, ale zaměří se na rozvoj informatického myšlení, které se v programování využivá. V informatice se zaměří na schopnost řešení vymyslet. Žáci se naučí přeměnit problém v úkol.

\section{Připravovaná změna výuky informatiky na základních školách}

Vzdělávání v České republice by mělo být $\mathrm{v}$ budoucnu více provázáno se světem informačních a komunikačních technologií a reagovat na technologický vývoj. Současné platné vzdělávací programy vznikaly více než před 10 lety a technologický vývoj šel dopředu. Na základě Ministerstva školství mládeže a tělovýchovy (dále jen MŠMT) provedených revizí je koncipován nový RVP pro základní vzdělávání, který se z hlediska informačních a komunikačních technologií nezaměřuje pouze na vytváření uživatelských dovedností, ale i na rozvoj tvưrčích schopností žáků. Uvažuje se, že vzdělávací oblast informační a komunikační technologie bude rozdělena do 2 oblastí, jak uvádí tehdejší náměstek ministra MŠMT J. Fidrmuc (2017):

Informatika a ICT

- Data, informace a modelování;

- $\quad$ algoritmizace a programování;

- $\quad$ informační systémy;

- počítač a jeho ovládání. 
Digitální gramotnost

- C Člověk, společnost a digitální technologie;

- tvorba digitálního obsahu;

- $\quad$ informace, sdílení a komunikace v digitálním světě.

Je záměrem, aby předmět informatika nově a ve větší míře pomohl žákům vymyslet řešení, umožnil rozvoj informatického myšlení a digitální gramotnosti, která je chápána jako klíčová kompetence potřebná k aktivnímu uplatnění ve společnosti a na trhu práce. Tak, jak je záměr připravován je zřejmé, že změny se dotknou v podstatě všech učitelů a budou na ně kladeny nové nároky. Učitel je klíčový aktér, který implementuje digitální technologie do školního vzdělávání.

Výuku informatiky je nutno vnímat jako proces pedagogický a zároveň i jako proces technologický, což pro školu představuje zajištění infrastruktury (vybavení učeben počítači, zajištění internetu).

\section{Pohled učitelů informatiky na v současnosti připravované kurikulární změny}

V březnu roku 2017 byly v Olomouci osloveny dvě základní školy, na kterých byly provedeny hloubkové rozhovory s učiteli informatiky na téma změna obsahu vzdělávání ve výuce informatiky. Aprobovaným učitelům jsme položili 6 otázek, směřujících do níže uvedených oblastí:

- $\quad$ srovnání RVP s předchozím vzdělávacím programem;

- aktuálnost RVP;

- $\quad$ začlenění nových poznatků z oblasti informatiky do výuky;

- $\quad$ začlenění programování a algoritmizace do výuky;

- $\quad$ zájem žáků o tento předmět;

- nutnost inovace současného RVP.

Dotazovaní učitelé vzhledem ke svému věku neměli možnost praktického srovnání s předchozími vzdělávacími programy, ale současný RVP považují za dostatečně variabilní (nesvazující) a mohou výuku přizpůsobit aktuálním trendům. Nicméně dle názoru dotazovaných učitelů není RVP zcela aktuální. Vyučující se snaží do výuky zařadit nová témata, např. operační systémy Android nebo iOS, chytré telefony a tablety. V souvislosti s výukou programování a algoritmizace učitelé uváděli, že pro žáky nejsou tato témata snadná a nejsou dostatečně vybavené učebny ani finance. Proto by se do povinné výuky zařazovat neměly, ale pro zájemce ano. Obecně je Informatika oblíbený př̀edmět.

V dalším kroku bylo realizováno výzkumné šetření na 2. stupni základních škol v Moravskoslezském kraji. Byli osloveni 4 učitelé a byl zjišt’ován jejich názor na plánované kurikulární změny ve výuce informatiky a ICT. Výzkum byl proveden v časovém horizontu jeden týden. Cílem bylo získat poznatky o vhodnosti volby výzkumných nástrojů.

V předvýzkumu byla zvolena kvantitativní metoda pedagogického výzkumu. Jedná se o Q-metodologii (viz W. Stephenson, 1993), což je statistická metoda, která ve výzkumech zjišt'uje v určité skupině respondentů, jak hodnotí určitou množinu objektů, přičemž těchto objekti̊ je velký počet. Q-metodologie je vhodná zejména k intenzivnímu zkoumání malých skupin osob, proto byli do předvýzkumu zapojeni 4 respondenti. V další fázi předpokládáme účast cca 30 respondentů. Přri využití Q-metodologie se 
předkládá zkoumaným osobám soubor (balíček) karet, na nichž jsou uvedeny objekty, jež mají hodnotit (např. výpovědi, názory apod.) s tím, že je mají roztř́idit podle určitého kritéria (M. Chráska, 2016).

Námi navržené q-typy (témata odrážející učivo), vychází ze současných učebnic informatiky viz D. Hawiger (2001), J. Vaníček, P. Řezníček a R. Mikeš (2004), L. Kovářová (2004) a P. Kmoch (1997), dále také $\mathrm{z}$ dřive i současně platných kurikulárních dokumentů a $\mathrm{z}$ ještě neschváleného návrhu na inovovaný RVP.

$\mathrm{V}$ předvýzkumu bylo respondentům předloženo 90 karet $\mathrm{s}$ otázkami $\mathrm{z}$ informatiky a informačních a komunikačních technologií, které respondenti třídili podle zadaných kritérií od nejdůležitějších po nejméně důležité. Následně byly jejich odpovědi v souladu s metodologicky obvyklým postupem vyhodnoceny pomocí výpočtu aritmetického průměru. Nejvíce preferované q-typy mají největši průměrné hodnocení a nejméně preferované q-typy mají nejmenší průměrné hodnocení.

Z provedeného předvýzkumného šetření vyplývá (viz tabulka č. 1), že učitelé základních škol upřednostňují uživatelské dovednosti typu bezpečnost práce, vyhledávání informací a práce $\mathrm{s}$ internetem. Dovednosti typu algoritmizace a programování nevnímají jako nutnost současné výuky informatiky.

\begin{tabular}{|l|l|l|}
\hline Pořadí & \multicolumn{1}{|c|}{ Q-typ } & \multicolumn{1}{|c|}{$\begin{array}{c}\text { Průměrné } \\
\text { hodnocení }\end{array}$} \\
\hline 1. & Zásady bezpečnosti práce & 9,00 \\
\hline 2. & Prezentace & 8,5 \\
\hline 3. & $\begin{array}{l}\text { Pravidla a rizika uveřejňování informací o sobě a o druhých } \\
\text { na internetu }\end{array}$ & 8,25 \\
\hline 4. & Vyhledávání informací na internetu & 8,00 \\
\hline 5. & Základy počítačové etiky & 8,00 \\
\hline 6. & Etická pravidla komunikace přes internet & 7,75 \\
\hline 7. & Zásady práce s počítačem & 7,75 \\
\hline 8. & Psychologická a sociální rizika práce s počítačem & 7,75 \\
\hline 9. & Vzorce a funkce (tabulkové editory a procesory) & 7,25 \\
\hline 10. & Grafy a diagramy (tabulkové editory a procesory) & 7,25 \\
\hline 11. & Organizace programú a dat v počítači (složky a disky) & 7,25 \\
\hline 12. & Záznam, zobrazení, ukládání, přenos a tisk dat & 7,00 \\
\hline 13. & Charakteristické parametry počítačů & 6,75 \\
\hline 14. & Vstupní a výstupní zařízení počítačových soustav (periferie) & 6,75 \\
\hline 15. & Počítačová grafika & 6,75 \\
\hline 16. & Soubory (typy, velikost a práce s nimi) & 6,75 \\
\hline 17. & Ochrana počítače (antiviry, hacking...) & 6,75 \\
\hline 18. & Práce s textovým editorem (Word atd.) & 6,75 \\
\hline 19. & Formulace požadavku při vyhledávání na internetu & 6,75 \\
\hline 20. & Bezpečnost práce v síti (hesla) & 6,75 \\
\hline 21. & $\begin{array}{l}\text { Tabulkové editory a procesory (charakteristika, využití, } \\
\text { principy) }\end{array}$ & 6,5 \\
\hline 22. & Hardware počítače (princip funkce, obsluha) & 6,5 \\
\hline 23. & Webové prohlížeče & 6,5 \\
\hline & & \\
\hline
\end{tabular}




\begin{tabular}{|c|c|c|}
\hline 24. & Ovládací prvky a nástroje operačního systému & 6,25 \\
\hline 25. & Algoritmizace úloh & 6,00 \\
\hline 26. & Digitalizace dat (text, obrázek, video a audio) & 6,00 \\
\hline 27. & Internetové adresy a domény & 6,00 \\
\hline 28. & Ukládání souborů $\mathrm{z}$ internetu & 6,00 \\
\hline 29. & Komprimace souborů & 6,00 \\
\hline 30. & Vektorová grafika & 6,00 \\
\hline 31. & Rastrová grafika & 6,00 \\
\hline 32. & Výukové (didaktické) programy & 6,00 \\
\hline 33. & Hraní didaktických her & 6,00 \\
\hline 34. & Operační systémy (základní funkce) & 6,00 \\
\hline 35. & Základní funkce grafického editoru & 6,00 \\
\hline 36. & Antivirové programy & 6,00 \\
\hline 37. & Zálohování dat & 6,00 \\
\hline 38. & Charakteristika a princip činnosti operačního systému & 5,75 \\
\hline 39. & Zpracování digitálních fotografií & 5,75 \\
\hline 40. & Př́ihlášení do a odhlášení ze systému & 5,75 \\
\hline 41. & Disky SSD, flash pamět'ové karty a USB disky & 5,75 \\
\hline 42. & Dodržování autorských práv & 5,5 \\
\hline 43. & Základní jednotky (bit, Bajt, Kilobajt, Megabajt...) & 5,5 \\
\hline 44. & Aktualizace operačního systému a aplikačních programů & 5,5 \\
\hline 45. & $\begin{array}{l}\text { Prevence zdravotních rizik spojených s dlouhodobým } \\
\text { užíváním výpočetní techniky }\end{array}$ & 5,25 \\
\hline 46. & Rozlišení a použití různých datových typů & 5,00 \\
\hline 47. & Komunikace prostřednictvím e-mailu & 5,00 \\
\hline 48. & Sociální sítě (Facebook, Twitter...) & 4,75 \\
\hline 49. & Skenování dokumentů a jejich úprava & 4,75 \\
\hline 50. & Práce s „,chytrým“ telefonem & 4,75 \\
\hline 51. & Tvorba webových stránek & 4,75 \\
\hline 52. & Internet (co to je, kdy vznikl, služby, možnosti připojení) & 4,75 \\
\hline 53. & Sestavování robotů (robotika) & 4,5 \\
\hline 54. & Práce s tabletem & 4,5 \\
\hline 55. & Databáze (tabulky, dotazy, formuláře, sestavy) & 4,5 \\
\hline 56. & Instalace a odebrání programů & 4,5 \\
\hline 57. & $\begin{array}{l}\text { Popis problému pomocí grafů, příp. dalších ikonických } \\
\text { modelů }\end{array}$ & 4,25 \\
\hline 58. & Počítačové sítě (vlastnosti, typy) & 4,25 \\
\hline 59. & Princip fungování ztrátové a bezeztrátové komprese dat & 4,00 \\
\hline 60. & Vývojové diagramy (algoritmizace) & 3,75 \\
\hline 61. & Znalost částí počítače (rozebírání a sestavování) & 3,75 \\
\hline 62. & Barevné modely RGB a CMYK & 3,75 \\
\hline 63. & Střih videa & 3,75 \\
\hline 64. & Pojem proměnná (algoritmizace) & 3,5 \\
\hline 65. & Matematický zápis algoritmu & 3,5 \\
\hline 66. & Historie počítačů & 3,5 \\
\hline
\end{tabular}




\begin{tabular}{|l|l|l|}
\hline 67. & Pojem cyklus (algoritmizace) & 3,25 \\
\hline 68. & Historie programování & 3,25 \\
\hline 69. & Programovací paradigmata & 3,25 \\
\hline 70. & Obsluha digitální kamery & 3,25 \\
\hline 71. & Sestavení a zápis algoritmu pro řešení problému & 3,00 \\
\hline 72. & Posloupnost př́kazú (algoritmizace) & 3,00 \\
\hline 73. & Podmíněné příkazy a operátory (algoritmizace) & 3,00 \\
\hline 74. & Příkazy programovacích jazyků & 3,00 \\
\hline 75. & Vlastnosti vybraných programovacích jazyků & 3,00 \\
\hline 76. & Hraní zábavních her & 3,00 \\
\hline 77. & Pojem, zápis a vlastnosti algoritmu & 2,75 \\
\hline 78. & Základní algoritmické př́́kazy & 2,75 \\
\hline 79. & Cyklus (zápis pomocí vývojového diagramu) & 2,75 \\
\hline 80. & Historie algoritmizace & 2,75 \\
\hline 81. & Programovací jazyky (charakteristika, rozdělení) & 2,75 \\
\hline 82. & Datové typy proménné & 2,5 \\
\hline 83. & Programovací nástroje (překladače, vývojová prostředí) & 2,5 \\
\hline 84. & Ladění programu (programování) & 2,5 \\
\hline 85. & Programovací metody (strukturované a objektové) & 2,25 \\
\hline 86. & Sekvenční uspoŕdání kódu (algoritmizace) & 2,00 \\
\hline 87. & Množiny (algoritmizace) & 2,00 \\
\hline 88. & Datové struktury (proměnná, pole, struktura) & 2,00 \\
\hline 89. & Zpo̊sob vývoje softwaru (kaskádový, iterační) & 2,00 \\
\hline 90. & Operace s vektory a maticemi (algoritmizace) & 1,5 \\
\hline
\end{tabular}

Tab. č. 1: Výsledné seřazení Q-typů podle průměrného bodového hodnoceni učiteli.

Po posouzení a zvážení průběhu sběru dat a jeho výsledků se ukázalo, že 90 q-typů je pro respondenty vysoký počet, a proto byl snížen na 60 q-typů (budou prezentovány v dalších publikacích spolu s výzkumnými závěry). Největší problémy činila skutečnost, že respondenti museli myšlenkově obsáhnout všech 90 q-typů a ty vzájemně hodnotit, porovnávat a třídit.

Při redukci byly uplatněny následující postupy. Některé q-typy spolu tematicky souvisely tak úzce, že byly sloučeny do jedné položky. Další q-typy byly vyloučeny úplně, jelikož vyvolávaly $v$ respondentech ne př́liš přesné představy, tzn. byly diskutabilní. To je z metodologického hlediska nepř́ipustné. Menší počet q-typů byl rovněž více či méně přeformulován do vhodnější (srozumitelnější) podoby.

Nad rámec uvedeného se na základě výsledků předvýzkumu potvrdilo, že je z hlediska aktuálních potřeb žádoucí ve výzkumu pokračovat a provést šetření na vzorku cca 30 respondentů. To se $z$ metodologického hlediska logicky předpokládá. Tím bude umožněno dosažení validních a reliabilních výsledků v podobě názorů učitelů na obsahové zaměření předmětu informatika. Pravděpodobně výsledky poukáží na nezbytnost realizace patřičného vzdělávání učitelů v rámce DVPP i změn v pregraduální príípravě. 


\section{Závěr}

Výzkumné šetření i přesto, že bylo v souladu s metodologickými zásadami z hlediska počtu respondentů ne př́liš velkého rozsahu, poskytlo cenné informace. Výsledky tedy nejsou zcela validní, ale i přesto podporují naše úvahy o odlišném smýšlení učitelů od pojetí, kterým se ubírají současné kurikulární inovace. Pokud by se v dalším kroku výzkumného šetření (na rozsáhlejším výzkumném vzorku) opravdu ukázalo, že v tomto článku uváděná zjištění jsou platná, bude nezbytné ovlivnit myšlení a nynější názory učitelů na tematické zaměření učiva $\mathrm{v}$ rámci předmětu informatika.

Současně upozorňujeme, že zjištěné výsledky nelze interpretovat tak, že by měly být vyučovány pouze uživatelské dovednosti jako doposud. Žáci se musí naučit ve světě informatiky a informačních technologií orientovat, musí získat potřebné tvůrčí kompetence, aby byli schopni plnohodnotného uplatnění v dnešním i budoucím světě. V této souvislosti je nezbytné zvážit i roli rodičů, měli by chápat důvody, proč je důležité rozvíjet digitální gramotnost a informatické myšlení u žáků základních škol.

Ve spojitosti s plánováním další fáze zkoumání se ukázalo, že zvolená metoda sběru dat, třídění kartiček, byla pro respondenty (vyučující), mj. i z časového hlediska velmi náročná. Pedagogové hodnotili 90 q-typů, a proto byl pro potřeby následného zkoumání počet snížen na 60 .

V rámci následného šetření bude provedena shluková analýza, jejímž cílem bude přiřadit respondenty (učitele) na základě podobnosti ke skupinám (shlukům). Přitom charakteristiky shluků ani jejich počet nejsou předem známy - musí být odvozeny z výzkumných dat, viz M. Chráska (2016). Při statistickém testování se mj. zaměříme na posouzení prrípadných odlišností mezi mladšími a staršími učiteli a taktéž na srovnání názorů učitelů ze školské praxe se studenty učitelství informatiky, kteří se na výkon profese učitele teprve připravují.

\section{Literatura}

Česká školní inspekce (2016). Žáci a ICT. Sekundární analýza výsledků mezinárodních šetreni ICILS $2013 \quad a \quad$ PISA $2012 . \quad$ Dostupné z: http://www.csicr.cz/html/SA_icils_pisa/html5/index.html?\&locale=CSY\&pn=1

Dostál, J. \& Wang, X. (2017). The curriculum content of informatics as a teaching subject at basic schools in the Czech republic between 1996 and 2005. In EDULEARN17 Proceedings. Madrid : International Association of Technology, Education and Development (IATED), s. 9525-9534.

Fidrmuc, J. (2017). Jsme připraveni? Strategie digitálního vzdělávání. Dostupné z: https://www.edulabcr.cz/wp-content/uploads/2017/11/1-Plneni-opatreni-Strategiedigitalniho-vzdelavani-Jaroslav-Fidrmuc.pdf

Hawiger, D. (2001). Učebnice a cvičebnice informatiky pro ZŠ: práce $s$ PC. Vyd. 1. Praha: Computer Press.

Chráska, M. (2016). Metody pedagogického výzkumu (2nd ed.). Praha: Grada.

Informatické myšlení (2017). Projekt pro podporu školské informatiky. Dostupné z: http://www.imysleni.cz/

Kmoch, P. (1997) Informatika a výpočetní technika pro základní školy. Praha: Computer Press.

Kovářová, L. (2004). Informatika pro základní školy. Kralice na Hané: Computer Media. 
Ministerstvo školství, mládeže a tělovýchovy (2017). "Informační a komunikační technologie," Rámcový vzdělávaci program pro základni vzdělávání. Dostupné z: http://www.msmt.cz/file/43792/

Národní ústav pro vzdělávání (2005). "Informační a komunikační technologie,” Rámcový vzdèlávací program pro základní vzdèlávání. Dostupné z: http://www.nuv.cz/file/493/ Národní ústav pro vzdělávání (2017). Informační a komunikační technologie," Rámcový vzdèlávaci program pro základni vzdělávání. Dostupné z: http://www.msmt.cz/file/43792/

Národní ústav pro vzdělávání (2018). Přehled úprav RVP ZV od roku 2004 do současnosti. Dostupné z: http://www.nuv.cz/t/prehled-uprav-rvp-zv-1

Neumajer, O. (2017). ČŠI o ICT ve školách: Zajištěni nedostatečné, počitače zastaralé, pripojení omezené, situace kritická. Praha: Wolters Kluwer.

Stephenson, W. (1993). Introduction to Q-Methodology. Operant Subjectivity, 17(1/2), $1-13$.

Vaníček, J. (2017). Výuka informatiky na základních školách se mění, zaměří se na programování Česká škola. Dostupné z: http://www.ceskaskola.cz/2017/12/vyukainformatiky-na-skolach-se-meni.html

Vaníček, J., Řezníček, P. \& Mikeš, R. (2004). Informatika pro základni školy: základy práce s PC: učebnice. Vyd. 1. Brno: Computer Press.

Wagner, J. (2008). ICT na základních a středních školách: je zle? Lupa.cz. Dostupné z: https://www.lupa.cz/clanky/ict-na-zakladnich-a-strednich-skolach-je-zle/ 